\title{
O TRATAMENTO DADO À LEITURA NA FASE FINAL DO ENSINO FUNDAMENTAL I: ENTRE O REAL E O IDEAL
}

\author{
Samara Moço Azevedo \\ Bianka Pires André
}

\begin{abstract}
RESUMO
Entendendo a leitura como uma atividade primordial para a formação social do aluno, pesquisou-se como se dão as práticas de leitura em sala de aula e quais as suas influências no processo de ensino e aprendizagem. Este estudo foi realizado em uma escola municipal de Campos dos Goytacazes com o objetivo de analisar sobre o tratamento dado à leitura por parte dos professores no 5o ano do ensino fundamental.
\end{abstract}

PALAVRAS-CHAVE: Leitura; Escola; Professor.

\section{Introdução}

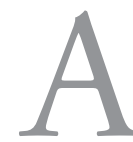

leitura é fundamental para a vida das pessoas, pois a partir do momento que se aprende a ler e interpretar, torna-se mais fácil reivindicar os direitos e participar efetivamente da sociedade. Nessa perspectiva, de acordo com os Parâmetros Curriculares Nacionais - PCNs (1997), o domínio da linguagem oral e escrita é de suma importância para a efetiva participação social, uma vez que é por meio dela que o homem se comunica, interage com o outro, tem acesso à informação, defende e expressa seus pontos de vista, produz conhecimento.

Este artigo apresenta os resultados de uma pesquisa que analisou o modo como a leitura vem sendo tratada em sala de aula pelos professores do quinto ano do ensino fundamental e quais são as perspectivas deles com relação à 
leitura, tendo em vista que a realidade escolar tem se afastado dos ideais estabelecidos pelos PCNs e defendidos pelos pensadores da educação. Ainda pensando na realidade escolar e nos ideais para a educação, será feito no presente artigo, um paralelo entre o ideal e o real, ou seja, entre aquilo que foi pensado para um sistema educacional de qualidade e o que realmente acontece "intramuros" escolares.

\section{O desafio da formação de novos leitores}

Desde o momento em que nasce, o indivíduo entra em contato com uma vasta gama de símbolos. A leitura se faz presente em todas as fases da vida e a todo tempo somos levados a ler, mesmo que em situaçóes simples do dia a dia como uma compra no supermercado, locomover-se por meio de transporte público ou propagandas em cartazes e outdoors, dentre outras.

Sendo assim, faz-se necessário que desde criança se domine os símbolos linguísticos para que futuramente esses indivíduos se tornem capazes de entender o mundo a sua volta, atuando efetivamente e criticamente na sociedade. Por esse motivo, os anos iniciais de escolarização são de suma importância para a formação dos educandos.

Ler pode parecer "fácil" se pensada como a ação de transformar a escrita em oralidade; entretanto, Foucambert (1994) defende que "ler não é apenas passar os olhos por algo escrito, não é fazer a versão oral de um escrito" (FOUCAMBERT, 1994, p. 5). Um leitor "competente" é aquele que ao ler determinado texto consegue interpretá-lo e também fazer uso do que foi lido, acrescentando conteúdos relevantes à sua "bagagem cultural". Ainda nessa mesma perspectiva, de acordo com os Parâmetros Curriculares Nacionais (1997):

A leitura é um processo no qual o leitor realiza um trabalho ativo de construção do significado do texto [...]. Não se trata simplesmente de extrair informação da escrita, decodificando-a letra por letra, palavra por palavra. Trata-se de uma atividade que implica, necessariamente, compreensão na qual os sentidos começam a ser constituídos antes da leitura propriamente dita (BRASIL, 1997, p. 53). 
Compreende-se, então, segundo os PCNs (1997), que a construção do entendimento do texto inicia antes da leitura propriamente dita. Isso significa que a apreensão do leitor com relação aos textos lidos não dependerá somente de sua interpretação, mas também das suas concepções de mundo, de seus conhecimentos prévios. Nas palavras de Paulo Freire (1989), “a leitura do mundo precede a leitura da palavra" (FREIRE, 1989, p. 9).

$\mathrm{O}$ ato de ler, por vezes, é considerado uma prática chata e desinteressante, principalmente entre os jovens, uma vez que geralmente o contato com os livros acontece de maneira obrigatória e sem autonomia de escolha. Sendo assim, levando em consideração que a leitura efetiva e significativa é aquela em que o texto faz sentido para o leitor, seria interessante que a prática de leitura acontecesse de maneira livre e desobrigada, sempre que possível, o que facilita a criação de laços entre leitor e leitura.

De acordo com Zilberman (2003), o surgimento dos elos entre leitor e obra acontece por meio da relação com a realidade. É preciso que o texto atenda às necessidades e expectativas do leitor porque, para além de qualquer estímulo exterior, há uma demanda interna que está ligada às necessidades existenciais desse indivíduo.

Despertar o gosto pela leitura em alguém é um processo, por vezes, lento e que acontece de maneira gradativa. Nesse sentido, para se obter maior êxito no incentivo ao gosto de ler é importante tentar criar a afetividade entre leitor e leitura, pois "se ensinamos uma criança a ler, mas se não desenvolvemos o gosto dela pela leitura, todo nosso ensino é em vão. Teremos produzido uma nação de 'alfabetizados analfabetos' - aqueles que sabem ler, mas não leem." (HULCK, 1973 apud HEATHINGTON, 2001, p. 221). Mikulecky (2001) defende que

O amor pela leitura e pela escrita torna a vida mais rica, mas é muito mais importante do que isso. Desenvolver o hábito de leitura e de escrita para toda vida ajuda a assegurar que nossos esforços educacionais não são em vão e que ganhos a curto prazo na escola não são perdidos pelo desuso durante os veróes e, na verdade, durante toda a vida (MIKULECKY, 2001, p. 277-278).

Sendo assim, é evidente que criar vínculos entre leitor e leitura é essencial quando se tem a intenção de se formar leitores para toda a vida. Contudo, 
apesar de toda teoria defendida pelos autores acima citados e pelos PCNs no que diz respeito à leitura, o que se tem visto nas escolas é uma realidade completamente diferente. A maioria das instituiçóes vem apresentando grande dificuldade em formar alunos com capacidade de ler. Verifica-se que o que tem sido feito, em larga escala, é capacitar os alunos para a comunicação, nada além disso. Assim como afirma Soares (2005): “[...] nosso problema não é apenas ensinar a ler e a escrever, mas é, também, e, sobretudo, levar os indivíduos - crianças e adultos - a fazer uso da leitura e da escrita, envolver-se em práticas sociais de leitura e de escrita" (SOARES, 2005, p. 18).

Desse modo, se a intenção da escola é fomentar o gosto pela leitura (principalmente no ensino fundamental), um dos fatores importantes para um significativo avanço na formação de leitores é providenciar condiçóes para tal, ou seja, criar um ambiente propício para esta ação. Por esse motivo, é importante que as escolas possuam bibliotecas com um vasto acervo, fazendo valer a Lei no $12.244 / 2010$ de 24 de maio de 2010, que prevê que os estados e municípios responsáveis pela educação básica, as universidades federais que possuem colégios de aplicação e as entidades mantenedoras das escolas privadas têm o prazo de dez anos para implantar bibliotecas em suas instituiçốes de ensino. No entanto, apesar da Lei das Bibliotecas já estar em vigor há seis anos, o cenário escolar brasileiro pouco parece ter mudado em relação a essa premissa.

Vale ressaltar que a maioria das crianças tem seu primeiro contato com os livros na escola, fato que torna a responsabilidade das instituiçóes de ensino e dos profissionais da educação ainda maior para com a formação de leitores. Sendo assim, outro fator importante para o fomento ao gosto de ler é a mediação dos professores na formação desses leitores. Corroborando com essa afirmativa, Johns e Vanleirsburg (2001) dizem que:

A possibilidade de desenvolver interesses e atitudes em relação à leitura é aumentada quando os professores compartilham seu amor pela leitura e dáo aos alunos oportunidade de desfrutarem os materiais impressos em um contexto mais amplo, o qual leva em consideração as condiçóes essenciais para a aprendizagem (JOHNS; VANLEIRSBURG, 2001, p. 118). 
A partir desta afirmação, evidencia-se a importância dos professores serem leitores, estando em contanto com diferentes leituras, pois "é impossível tornarmos nossos alunos pessoas que leem e escrevem se nós mesmos, professores, não temos sido leitores [...]" (KRAMER, 2001, p. 103). É nesse sentido que se faz necessário refletir sobre a forma como se dá o incentivo ao hábito de ler e sobre os meios pelos quais esse incentivo acontece, a fim de identificar as metodologias que funcionam e aquelas que encontram-se defasadas perante as necessidades da realidade escolar atual, evitando, assim, desvalorização ainda maior do ato de ler e, consequentemente, do ensino.

Formar novos leitores não é tarefa fácil e demanda a união de alguns fatores. Pouco vale possuir uma ótima estrutura física e material, se professores e alunos não fazem uso e/ou não têm acesso a elas. Do mesmo modo, não adianta muito o professor querer incentivar o hábito de ler, se a escola não possuir suporte para atender às demandas.

Por outro lado, pode-se perceber que à medida que o tempo avança, ao professor tem-se atribuído ainda mais funçóes. Funçóes essas que muitas vezes, não cabem nem a ele e nem a escola. Ainda, atrelado a isso, vêm também diversos problemas educacionais que ficam a cargo dele tentar solucioná-los ou, ao menos, minimizá-los, como o desinteresse dos alunos, a falta de condições de trabalho, concorrência com os meios de comunicação em massa e com as novas tecnologias (cada vez mais avançadas).

Durante os últimos 50 anos, o mundo, de modo geral, passou por grandes transformaçóes. Houve um grande avanço tecnológico, científico e até mesmo cultural. A partir dessas questóes, pode-se observar que tudo parece ter avançando, mas a sensação é que a escola continua estagnada. Na verdade, aconteceram mudanças, algumas específicas até trouxeram grandes benefícios para a educação, mas, ainda assim, o modelo educacional vigente deixa a desejar em muitos aspectos, tendo em vista que alguns problemas de anos atrás perduram até os dias atuais. Segundo as palavras de Zilberman (2008):

Tudo o que mudou parece ter mudado para melhor - menos a escola, com suas consequências: a aprendizagem dos alunos, a situação do professor, as políticas públicas dirigidas à educação, para não se mencionarem as condiçóes de trabalho, onde predomina a insegurança, e o espaço físico das salas de aula, degradado e degradante (ZILBERMAN, 2008, p. 14). 
Nos últimos anos, a escola vem enfrentado grandes problemáticas. De acordo com Soares (2002), esses problemas começaram a tomar força após o processo de democratização do ensino, em que as inúmeras transformaçóes sociais refletiram na mudança do perfil dos alunos. Nesse momento, a escola se vê perante um público de uma realidade diferente a que ela costumava atender.

Ainda na perspectiva de Soares (2002), a solução para tais problemáticas exige uma transformação social que vai além dos muros das escolas. Deve haver uma tomada de consciência em que os indivíduos se percebam como um ser social, ou seja, uma parte essencial da engrenagem que faz a "máquina" - sociedade - funcionar de maneira adequada. E é nesse sentido que se faz necessário que a escola deixe de ser a mantenedora da estabilidade do sistema e se torne uma instituição que leve o aluno a se perceber como cidadão e a exercer a cidadania. Isso pode se dar por meio do incentivo ao hábito de ler e pelas práticas sociais de leitura, maneira pela qual o indivíduo começa a criar condições de questionar, criticar, interagir e atuar efetivamente na sociedade.

É fato incontestável que as tecnologias surgem a partir das transformações sociais, uma vez que em muito auxiliam a vida e a comunicação humana. As possibilidades que as Novas Tecnologias trazem são tantas, que tornar a escola atrativa não é uma tarefa nada fácil. Com todas essas mudanças, recai sob os professores a responsabilidade de deixar os alunos atraídos pelo universo escolar, assim como ressalta Coelho (2008):

É esse o tempo de mutação que nos desafia a colaborarmos com as mudanças ou a resistirmos a elas. Desafio difícil de ser enfrentado, principalmente por aqueles que, direta ou indiretamente, estão ligados à Educação e à necessária reformulação dos processos de Ensino em crise (COELHO, 2008, p. 76).

Sendo assim, vale ressaltar que é indispensável levar em consideração que o aluno é parte integrante da sociedade e, como tal, está suscetível às mudanças e sofre as influências das transformaçóes sociais, seja de cunho cultural, tecnológico ou ideológico.

Entendendo que há o surgimento de uma nova geração com características e necessidades diferentes das geraçóes anteriores, torna-se indispensável que a escola e os profissionais envolvidos no processo de ensino repensem, re- 
flitam e reavaliem seus métodos, pois, caso contrário, adentraremos numa crise educacional maior ainda, visto que as transformaçóes sociais (e para essa nova geração, principalmente as Novas Tecnologias) trouxeram consigo grandes mudanças na forma de pensar, viver, escrever e falar dos indivíduos. "O grande desafio a ser enfrentado pela Escola em crise está, hoje, no confronto entre o atual império da imagem (o cyberespaço) e o inesgotável poder construtor/ ordenador da palavra (o mundo letrado, o livro)." (COELHO, 2008, p. 78).

Com o processo de avanço tecnológico e principalmente com o advento da internet, a língua, de um modo geral, vem sofrendo grandes mudanças. Como parte integrante da sociedade, a língua não se mantém estática diante das transformaçóes que ocorrem com o passar dos anos. Assim como afirma Bakhtin (1981): “a língua vive e evolui historicamente na comunicação verbal concreta [...]” (BAKHTIN, 1981, p. 121 apud SOUZA; GOMES, 2008, p. 72). Nesse sentido, não seria diferente com o imediatismo do mundo tecnológico.

Dessa forma, é imprescindível que os indivíduos acompanhem as mudanças ocorridas na sociedade, buscando adaptar-se a elas, já que "nenhuma sociedade fica estática diante do tempo [...]" (SOUZA; GOMES, 2008, p. 51). E sendo "compreendida como fato social, a Educação não está descolada da realidade [...]" (SOUZA; GOMES, 2008, p. 36). Por esse motivo, deve-se repensar o modelo educacional para que a escola consiga adaptar-se às mudanças sociais.

É evidente que com a velocidade das informações e das transformações sociais a escola e, consequentemente, os professores têm se deparado com novos desafios constantemente. Desafios esses que os levam a reflexão e a tentativa de inovação e reinvenção de sua prática diariamente, principalmente acerca do fomento do gosto pela leitura.

O reflexo do "hábito de não ler" pode ser percebido, sobretudo, no desempenho do aluno em avaliaçóes internas e notado nitidamente nos resultados das avaliaçóes externas, como a Prova Brasil, que avalia o desempenho de alunos de 5o e 9o ano de escolas públicas urbanas, e o PISA (Programa Internacional de Avaliação de Alunos), no qual o Brasil ficou em 55 posição em leitura no ano de 2012, dentre 65 países avaliados.

Claro que é preciso olhar com maior atenção esses modelos avaliativos educacionais, pois, além dos resultados, deve-se levar em consideração vários fatores que influenciam no rendimento das instituiçóes de ensino. Entretanto, 
levando-se em conta que, para obter êxito em uma avaliação, é essencial ler bem e possuir capacidade interpretativa, torna-se inegável que o hábito de ler influencia diretamente no desempenho do aluno ao responder às questóes de uma prova.

De acordo com o Relatório Pisa 2012, os alunos brasileiros "não são capazes de deduzir informaçóes do texto, estabelecer relaçôes entre diferentes partes do texto e não conseguem compreender nuances da linguagem" (PISA, 2012). Sendo assim, a falta de habilidade dos alunos com a leitura pode ser uma das causas para a falta de êxito em avaliações de desempenho educacional, seja em larga escala ou não.

Percebe-se que incentivar o hábito de ler tem se tornado cada vez mais distante da realidade educacional vigente, uma vez que muitos eventos e aspectos influenciam diretamente nessa prática. $\mathrm{O}$ professor, então, vive um duplo desafio diariamente: o desafio de incentivar a leitura e o desafio de tornar a escola um ambiente atrativo, visto que um mundo de possiblidades que se encontra ao alcance dos alunos por meio de alguns cliques. Além disso, há a fragilidade da instituição de ensino devido à sua defasagem quanto ao tempo e às necessidades de uma sociedade que se apresenta em constante mutação.

\section{A pesquisa e seu contexto}

A pesquisa teve por objetivo analisar a abordagem dada à leitura por parte dos professores no quinto ano do ensino fundamental em uma escola municipal localizada na cidade de Campos dos Goytacazes - RJ, que obteve maior êxito no Índice de Desenvolvimento da Educação Básica (IDEB). Nesse sentido, buscamos atentar para as possíveis influências do uso da leitura como propulsora para os avanços na qualidade do ensino nesta instituição.

A análise foi feita a partir da articulação entre as informaçóes obtidas por meio da observação do cotidiano escolar e entrevistas realizadas com as professoras do quinto ano do ensino fundamental I e com a diretora da escola.

É importante ressaltar que para a preservação da identidade das professoras e da diretora, os nomes serão ocultados e em seu lugar será utilizado Diretora, Professora 1 (responsável pelas disciplinas Língua Portuguesa, Ciências e Artes) e Professora 2 (responsável pelas disciplinas Matemática, História e Geografia). 
O estudo foi realizado na Escola Municipal Ferroviário Jacy da Silva Barbeto que funciona em tempo integral. No ano de 2014, a escola continha 130 alunos matriculados e frequentando o ensino fundamental I (a instituição só atende a esse segmento). Apesar de ser localizada em um bairro nobre da cidade de Campos dos Goytacazes - RJ, a maior parte dos alunos do Ferroviário (como é chamado pelos funcionários) é oriunda de comunidades vizinhas com realidade totalmente diferente do local onde se situa a escola. Apenas cerca de 30 alunos moram na parte central da cidade.

A escola foi fundada pelo Sindicato dos Ferroviários e, por esse motivo, recebe esse nome. Ela possui aproximadamente 35 anos de funcionamento e sempre foi de tempo integral. Atualmente, a instituição é municipalizada e mantida pela Prefeitura de Campos.

Nos últimos anos, o Ferroviário passou por inúmeros problemas, dentre eles a distorção idade/série ocasionada pela repetência (cerca de $80 \%$ dos alunos em 2010), um dos motivos que o levou a obter uma média insatisfatória, alcançando apenas 2.9 no IDEB de 2009. Entretanto, a partir do ano de 2010, a realidade da instituição começou a mudar. A qualidade do ensino avançou de maneira significativa. Em pouco tempo, esse avanço pôde ser notado nos resultados do IDEB, que em 2013 alcançou a média de 6.2, ultrapassando muito, as metas projetadas para o ano, inclusive a que foi projetada para o ano de 2021, que é 4.9.

A estrutura física da instituição não é das melhores. O espaço é pequeno, fato que impossibilita que as salas sejam amplas. Estas não possuem janelas e contam apenas com o ventilador que não dá conta do calor em dias quentes. A escola não possui biblioteca e, nela, ainda se utiliza quadro de giz. Os computadores disponíveis para uso dos alunos não funcionam. E para recreação, a escola conta com uma quadra a céu aberto que em tempos de chuva não pode ser utilizada pelos alunos que acabam não brincando nos intervalos das aulas.

A turma selecionada como alvo da pesquisa foi o $5^{\circ}$ ano do ensino fundamental. A escolha por tal turma deve-se ao fato da Prova Brasil (um dos meios utilizados para gerar o IDEB) ser aplicada em turmas de $5^{\circ}$ ano e também porque, nessa fase, os alunos já estão alfabetizados, o que torna seu contato com a leitura bem maior do que nos anos anteriores.

A classe era relativamente pequena (17 alunos), talvez por isso a indisciplina e o mau comportamento não foram notados. Os alunos eram, em 
geral, participativos e conseguiam acompanhar o ritmo das aulas com facilidade. Não havia problemas com faltas, todos frequentavam regularmente. Eles tinham entre 10 e 11 anos de idade, exceto um ou dois que estavam com distorção idade/série. O horário de aula é das 08 horas até às 16 horas, com intervalo para almoço e lanche da tarde todos os dias. Em alguns dias da semana, também há intervalos durante as aulas para projetos, recreação e aula de música. Pela manhã, os alunos têm aula com a professora 1 , responsável pelas disciplinas Língua Portuguesa, Ciências e Artes, e, no período vespertino, com a professora 2, de Matemática, História e Geografia.

\section{O relacionamento dos profissionais da educação com o ato de ler e o tratamento dado à leitura em sala de aula}

É extremamente difícil incentivar um hábito em alguém se nós mesmos não o possuímos. Sendo assim, se o intuito é fazer com que esse incentivo seja significativo, devemos nós mesmos, antes de tudo, nos certificarmos de que acreditamos na importância daquilo que nos propomos a incentivar. Caso contrário, será apenas uma tentativa falha, visto que desistiríamos da ideia ao nos depararmos com a primeira adversidade. É nesse sentido que Johns e Vanleirsburg (2001) afirmam que não há um modelo mais efetivo dentro da sala de aula do que um professor que ame os livros e a leitura.

Ao questionar as professoras sobre qual o entendimento que elas tinham de leitura e o que a leitura representava na vida de cada uma, as respostas foram as seguintes:

A leitura é a base de qualquer meio de estudo, né? A partir da leitura que a gente aprende. Quem sabe ler, consegue qualquer outro tipo de conhecimento. Porque a partir dela que a gente vai buscando outros conhecimentos. (Professora 2-Matemática, História e Geografia)

[...] o entendimento meu de leitura é um entendimento mais amplo de leitura, não é leitura só da palavra, é a leitura de mundo. Então, a leitura é o que abre as portas do mundo pra gente, porque não adianta você lê apenas palavras. Porque, por exemplo, eu já passei por várias situações em que pessoas que não sabiam ler elas 
se achavam inferiores as outras, elas se tornavam pessoas perdidas. [...] Então, a gente vê o quanto a leitura faz falta na vida das pessoas. [...] a leitura é imprescindivel pra gente. (Professora 1 Português, Ciências e Artes)

É notório que as duas acreditam que a leitura é essencial em nossas vidas, inclusive para realizar atividades simples do dia a dia e atribuem essa importância às suas vidas também. Entretanto, ao perguntar se elas gostavam de ler e qual o tipo de leitura mais lhes agradavam, dentre as duas, uma respondeu de forma positiva, mas reconheceu que não lia com a frequência de que gostaria de fazê-lo, alegando falta de tempo.

Eu, pra falar a verdade, náo gosto muito de ler. Mas foi o que eu falei: 'como ela é a base, a gente meio que tem uma obrigaçâo.' [...] a leitura pra mim, ela é suma importância. Essencial para o ser humano. Eu gosto muito de ler sobre documentários. Eu gosto de saber de coisas cientificas. Eu gosto muito de ler (isso ai eu gosto mesmo) sobre cabelos e reportagens. Eu gosto de saber das notícias. (Professora 2 - Matemática, História e Geografia)

Sim, eu gosto de ler, sim. Apesar do tempo ser extremamente curto e a vida, às vezes, traz tanta informação pra gente o tempo inteiro que a gente acaba ficando mais preso às questóes eletrônicas do que de livros mesmo. Mas eu tenho paixão por livros e apesar do pouco tempo que tenho pra lê-los, eu tenho alguns que eu sou apaixonada [...]. Eu gosto de romances, como sempre, acho que a maioria das mulheres são assim, mas não só isso. A leitura informativa. Raramente eu vejo $T V$, então, as informaçóes que eu tenho vem por meio digital. Eu to sempre lendo, reportagens, de forma digital. Eu gosto muito de ler, apesar do pouco tempo que tenho pra isso. (Professora 1 - Português, Ciências e Artes)

É evidente que apesar das professoras acreditarem na importância da leitura, ainda há um distanciamento entre elas e o ato de ler, fato que pode influenciar diretamente em sua prática docente. 
Por outro lado, pensando no cotidiano escolar, o livro didático se faz mais presente neste contexto do que os livros literários e, algumas vezes, é a única fonte de leitura e de conhecimento para o aluno. Por esse motivo, é de suma importância que o material didático seja de qualidade e atenda à necessidade do professor ao ensinar e do aluno ao aprender. Sendo assim, foi imprescindível analisar o tratamento dado à leitura em sala de aula, buscando observar se há o incentivo por parte dos professores de levar o aluno a ler literaturas extraescolares e se o livro didático adotado pela Prefeitura de Campos dá o enfoque necessário à leitura.

Antes da análise, vale ressaltar que a Prefeitura de Campos adota os livros didáticos do Grupo Expoente. Esse grupo é da cidade de Curitiba/PR, onde a realidade educacional é bem diferente da vivida em Campos dos Goytacazes/ RJ. Buscando no site do INEP o IDEB dessas cidades, é visível a discrepância da qualidade do ensino entre uma cidade e outra. Nesse sentido, é inevitável o distanciamento entre a realidade escolar do Ferroviário e os conteúdos contidos no livro didático. Esse distanciamento torna-se ainda mais evidente a partir das palavras das professoras e da diretora ao serem perguntadas se o livro didático adotado pela Prefeitura de Campos tem dado o enfoque necessário à leitura. Segundo elas:

Muita coisa. Pra mim, sim. Ele é voltado na leitura e na interpretação. Esse que está adotado pelo Expoente, muitas crianças têm até dificuldade porque ele é focado na leitura e na interpretação. (Diretora)

Olha, ele tem textos até bons, só que não é condizente com a nossa realidade, né? [...] Ele tem textos enormes que as crianças não estão preparadas. [...] Não é a realidade da nossa cidade. São textos muito grandes, muito difíceis, às vezes, é um conteúdo que as crianças não têm vontade de ler porque não entendem. Então, eu sei que talvez aquele texto seria o certo para a idade, mas é uma coisa que não está dentro da realidade das crianças da Prefeitura de Campos. Eles não têm esse incentivo em casa. Então, quando chega na escola e se depara com um texto muito complexo, não vão ter gosto [...] (Professora 2 - Matemática, História e Geografia) 
Olha, [...] Todo material didático, ele tem seus prós e seus contras. Acredito que seja incompleto? Sim! Como nenhum material didático é completo. Só que o material Expoente especificamente, que é adotado pela Prefeitura [...] se você trabalhar da forma em que você acha adequada trabalhar o material, ele é interessante. Incompleto, porém interessante. [...] Eu só acredito que a interpretação de textos desses livros é um pouco precária porque existe muito mais coisa a ser explorada do que o que eles exploram. [...] Eu acredito que seja um material regular, mas [...] poderia ser um pouco melhor? Poderia! Só que também existem muitos profissionais que pegam esses materiais e não trabalham de maneira adequada. [...] Então, se as pessoas não exploram isso de uma forma adequada, não há material didático que seja bom. (Professora 1 - Português, Ciências e Artes)

Para a diretora, o livro dá o enfoque necessário, porque seus conteúdos de leitura e interpretação são complexos. O problema da complexidade é que quando ela não é dosada pode acabar no distanciamento do aluno com o ato de ler e não na aproximação, que seria o objetivo. Isso se explica, como foi apresentado pela professora 2 (Matemática, História e Geografia), pelo fato do material ser voltado para uma realidade totalmente diferente da vivenciada pelos alunos da Prefeitura de Campos. Nessa perspectiva, as pesquisas de Vygotsky (1998) já enfatizavam a importância da proximidade do indivíduo com os variados níveis de conhecimento como fatores essenciais para a aprendizagem. Segundo o autor, a Zona de Desenvolvimento Proximal,

É a distância entre o nível de desenvolvimento real, que se costuma determinar através da solução independente de problemas, e o nível de desenvolvimento potencial, determinado através da solução de problemas sob a orientação de um adulto ou em colaboração com companheiros mais capazes (VYGOTSKY, 1998, p. 112).

Portanto, seria interessante que o livro didático e seus conteúdos fossem condizentes com as necessidades educacionais de cada lugar para que ele não 
entre em desuso e nem comprometa a aprendizagem do aluno, tendo em vista sua utilidade como uma ferramenta pedagógica em sala de aula.

Contudo, a professora 1 (Português, Ciências e Artes) defende a importância do uso adequado do material, visto que o livro didático deve servir de apoio para o professor e não precisa, necessariamente, ser seguido à risca. Nesse sentido, é imprescindível que a escola disponha de um material didático com certo grau de qualidade, mas o mais importante é o professor saber aproveitá-lo da melhor maneira possível. Corroborando com a perspectiva do uso do livro didático como ferramenta de apoio para o professor, Magda Soares (2002), em entrevista cedida ao programa Salto para o Futuro do canal TV Escola, diz que

[...] há o papel ideal e o papel real. O papel ideal seria que o livro didático fosse apenas um apoio, mas não o roteiro do trabalho dele. Na verdade isso dificilmente se concretiza, não por culpa do professor, mas de novo vou insistir, por culpa das condiçôes de trabalho que o professor tem hoje. Um professor hoje nesse país, para ele minimamente sobreviver, ele tem que dar aulas o dia inteiro, de manhã, de tarde e, frequentemente, até a noite. Então, é uma pessoa que não tem tempo de preparar aula, que não tem tempo de se atualizar. A consequência é que ele se apoia muito no livro didático. Idealmente, o livro didático devia ser apenas um suporte, um apoio, mas na verdade ele realmente acaba sendo a diretriz básica do professor no seu ensino (SOARES, TV Escola/MEC, 2002).

Desse modo, levando em consideração que há uma grande diferença entre o uso ideal e o uso real do livro didático, torna-se notória a necessidade do professor rever suas práticas pedagógicas voltando uma maior atenção ao uso do livro didático para não fazer do mesmo 'muletas' durante o ato de ensinar.

Diferentemente dos livros didáticos, os livros literários possuem uma presença em menor escala na vida escolar dos alunos. Entretanto, isso não faz deles menos valiosos, pelo contrário, eles são muito importantes no contexto escolar, uma vez que possibilitam ao aluno maior contato com diversificados gêneros textuais. Como afirmam os PCNs (1997), é 
[...] necessário contemplar, nas atividades de ensino, a diversidade de textos e gêneros, e não apenas em função de sua relevância social, mas também pelo fato de que textos pertencentes a diferentes gêneros são organizados de diferentes formas. A compreensão oral e escrita, bem como a produção oral escrita de textos pertencentes a diversos gêneros, supóe o desenvolvimento de diversas capacidades que devem ser enfocadas nas situaçóes de ensino. (BRASIL, 1997, p. 23-24).

A partir do que foi dito, se levarmos em consideração o princípio de que os livros extraescolares são uma inesgotável fonte de diversidades textuais, é incontestável a essencialidade do seu uso no ambiente escolar. Por esse motivo, na tentativa de analisar o uso desses livros em sala de aula, a diretora e as professoras foram questionadas quanto ao incentivo à leitura de literaturas extraescolares e o meio utilizado para transformar as atividades de leitura algo mais prazeroso e produtivo para os alunos. As respostas recebidas foram as seguintes:

Incentivo sim! Eu já pedi até um dia da leitura aqui na escola aos professores, mas eles alegam que é muito corre, corre, de muito conteúdo pra dar e acaba não tendo. E algo mais produtivo e prazeroso o aluno também tem que chegar e ele escolher o material que ele quer ler e trabalhar e não trabalhar por imposição. [...] Pra mim, acho que pra se tornar prazeroso o aluno tem que escolher. (Diretora)

Eu incentivo sim! Eu mostro pra eles o quanto é importante a gente lê. O quanto é importante a gente saber. Eu falo até assim: 'mesmo que seja uma revista de fofoca.' Ao ler eles estão desenvolvendo a capacidade de interpretar. Então, eu incentivo qualquer tipo de leitura, né?(Professora 2 - Matemática, História e Geografia)

Olha, eu sempre costumo conversar muito com os meus alunos, às vezes, a gente de um conteúdo surge um comentário sobre uma coisa, $e$ dai a gente vai. Eu meio que eu viajo junto com eles. É como se mostrasse pra eles que existem coisas fora da escola que podem 
ser tão interessantes que eles acabam perdendo por não buscar. Ai eu conversei com eles sobre a questão de bibliotecas que existem. Entendeu? [...] eu sempre incentivo que eles estejam buscando leituras fora daqui. (Professora 1 - Português, Ciências e Artes)

A partir das respostas acima, percebe-se que todas dizem incentivar esse tipo de leitura. Todavia, a falta de tempo aparece mais uma vez como empecilho para essa prática.

A diretora ressaltou que o mais interessante a se fazer é evitar a leitura por imposição, estimulando no aluno a descoberta do tipo de leitura que mais lhe agrada para possibilitar a ele maior prazer ao mesmo durante o ato de ler. Diante disso, é relevante levar em consideração a defesa de Bamberg (1987) sobre a ligaçáo de prazer entre leitor e texto. $\mathrm{O}$ autor entende que para se adquirir o hábito de ler, se deve instigar o prazer no leitor. Em consonância a essa ideia, Lobato (1969) afirma que "o menino aprende a ler na escola e lê em aula, à força os horrorosos livros de leituras didáticas que as indústrias do gênero impingem nos governos. [...] Aprende assim [...] a considerar a leitura como um instrumento de suplício" (LOBATO, 1969, p.85). Com base na ideia acima defendida, constata-se a grande influência do prazer a partir de escolhas individuais na conquista do hábito de ler.

As professoras alegam que incentivam a leitura em sala de aula. A professora 2 (Matemática, História e Geografia) estimula seus alunos a lerem até mesmo sobre assuntos irrelevantes, pois, segundo ela, o mais importante é que eles estejam lendo e não o que de fato, estão lendo, salientando a importância das chamadas "leituras iscas" (ANDRÉ et al., 2015), que são os textos com um menor grau de complexidade e em geral do gosto do aluno, utilizados como porta de entrada para o mundo da leitura. No entanto, a professora 1 (Português, Ciências e Artes) acredita que a criação do hábito começa quando o educando é levado a buscar sobre temas que são de seu interesse e, nesse sentido, automaticamente, começa a se aproximar o leitor do ato de ler.

Todas as colocaçóes são pertinentes. Ainda mais se levarmos em conta que cada indivíduo possui uma realidade sociocultural e diferentes formas de ver o mundo, circunstâncias que determinam a motivação que o levará a se aproximar do mundo da leitura. 
Todavia, ainda que as professoras tenham afirmado que estimulam os alunos a lerem literaturas extraescolares, durante as observaçóes em sala de aula, poucas foram as vezes que presenciei esse uso. A professora 1 (Português, Ciências e Artes) foi a única que promoveu atividades de leitura e produção de texto enquanto estive presente. A primeira atividade consistia na leitura em voz alta de um pequeno livro de fábula escolhido pelo aluno; ao final ele deveria explicar o que entendeu da história para todos da classe. A segunda atividade era uma proposta do livro didático. O aluno deveria ler um texto e, em seguida, produzir outro com base em aspectos preestabelecidos pelo livro. A turma, em geral, se saiu muito bem durante a realização dessas atividades. Alguns tiveram um pouco mais de dificuldade que outros, mas isso não comprometeu em nada o resultado que era esperado. A professora, por meio de conversa informal, alegou que em todo bimestre, realiza esse exercício de leitura em voz alta seguido da interpretação do que foi lido para aferir o grau de leitura de seus alunos, pois são os resultados adquiridos que irão direcioná-la no processo de intensificação ao incentivo das práticas de leitura em sala e o "treinamento" em casa, de acordo com cada aluno.

Nesse sentido, por mais que haja o discurso positivo ao fomento do hábito de ler, ainda é evidente que o incentivo dessas atividades parte muito mais do professor de Língua Portuguesa e Literatura do que de professores das demais disciplinas. Entretanto, se entendida como uma prática social, a ação de instigar nos alunos o gosto pela leitura deveria ser responsabilidade de todos sem eximir por grau de maior ou menor compromisso de uns em detrimento de outros. Portanto, vale ressaltar as palavras de Soares (2002), quando ela afirma que ler e escrever é um compromisso de todas as áreas do conhecimento, mas

[...] a tendência é julgar que cabe ao professor de Português ensinar a desenvolver habilidades de leitura e de escrita. Frequentemente, professores das outras disciplinas se queixam com o professor de Português de que os seus alunos náo estáo sabendo compreender o problema de Matemática, o texto de História, o texto de Ciências. Na verdade, essa competência, essa responsabilidade não é só do professor de Português, nem o professor de Português é inteiramente competente para desenvolver 
habilidades de leitura de um problema de Matemática, por exemplo. Porque tem uma terminologia específica, tem uma forma específica de se apresentar, como o livro de Ciências, como o livro de Geografia. [...] Então, cabe a eles desenvolver essas habilidades de leitura e de escrita também (SOARES, TV ESCOLA/ MEC, 2002).

A autora acredita que isso acontece porque os professores de outras áreas, que não a de Português, não possuem em sua formação um enfoque para a leitura e a escrita, o que acaba por não habilitá-los a reforçar esses tipos de atividades em suas áreas. Soares deixa claro que, para se mudar esse quadro, deve-se reformular o curso de formação desses professores, introduzindo alguma disciplina na área de leitura e produção de texto. Desse modo, eles conseguiriam ter maior facilidade ao trabalhar com leitura e interpretação, uma vez que cada disciplina demanda uma estratégia diferente de leitura para a compreensão do conteúdo.

A partir do que foi dito, percebe-se que a leitura e a interpretação de texto são a base para se realizar atividades, inclusive as de caráter avaliativo. Tomando essa premissa, foi relevante questionar se as entrevistadas acreditavam que a leitura e a interpretação foram importantes para esse avanço no IDEB, a unanimidade foi evidente. Sobre a questão "Você acha que a leitura e a interpretação podem ser importantes para esse avanço?", as afirmaçóes foram as seguintes:

Muita coisa! [...] A gente está vendo alguns alunos que estão pra perder devido à falta de interpretaçáo nas questóes da prova. Sabem o conteúdo mas, [...] não tem a interpretação do que é pra ser respondido. (Diretora)

Com certeza! Porque foi o que eu disse inicialmente, qualquer disciplina, matemática, você precisa ler e interpretar pra resolver, porque tudo é envolvido na leitura. As provas de matemática hoje em dia mesmo, a gente dá todo com problemas. Por quê?? Porque eles têm que entender pra responder. Não é somente fazer conta. Fazer conta qualquer um faz. Então, a leitura é de suma importância e a interpretação, pra mim, é a base mesmo de tudo. (Professora 2 Matemática, História e Geografia) 
Com certeza! Diversos os projetos que são feitos são voltados à leitura e à interpretaçáo de texto porque eu sempre converso com meus alunos e sempre conversava com eles em outras salas também que não adianta você: 'Ai tia, leitura e interpretação de texto é em português.' Eu falo: 'Não! E história você consegue estudar história sem interpretar o texto, o que o autor tá dizendo?' 'Ah... Não! Ah... tia, mas matemática não tem nada a ver.' Ai eu falei assim: 'Então eu vou te dar um problema, se você não souber interpretar você não resolve.' Eles falaram assim: 'É tia, não tem jeito! A gente não tem como fugir de leitura.' Ai eu falei: 'Não tem. Então vamos ler.' É esse estímulo que a gente tem que dar a eles, né? (Professora 1 Português, Ciências e Artes)

Dessa maneira, levando em consideração que para realizar qualquer avaliação é preciso saber ler e interpretar, tornam-se inquestionáveis as influências da leitura e da capacidade interpretativa na obtenção de bons resultados. No entanto, isso só é possível quando a instituição conta com profissionais qualificados e engajados na ascensão da qualidade de ensino em suas unidades de trabalho.

\section{Conclusão}

A escola, como espaço de circulação da leitura, tende, muitas vezes, à obrigatoriedade do ato de ler, o que resulta no enfraquecimento dos laços de prazer entre leitura e leitor, levando o aluno ao desinteresse de um hábito que pode trazer muitos benefícios a ele.

Dessa forma, o objetivo desse trabalho foi conhecer e analisar como se dá o tratamento à leitura por parte dos professores em uma escola bem-sucedida de acordo com o IDEB, tendo como o enfoque a verificação das práticas pedagógicas que têm levado a instituição ao êxito no processo de ensino e aprendizagem.

Compreendemos que, no sistema educativo, e. consequentemente, no ensino da leitura, ainda há uma lacuna muito grande a ser preenchida entre o real e o ideal. Na tentativa de encurtar essa distância, é preciso que ocorra uma mobilização em massa, ou seja, todos unidos buscando dar novos rumos à realidade que temos hoje, fazendo com que o ideal deixe de ser uma utopia e passe a ser o modelo educativo real. 
Nesse sentido, precisamos de qualidade na estrutura física sim, mas mais que isso, na atual conjuntura da educação brasileira, precisamos de profissionais engajados na busca da qualidade do ensino, pois o aprendizado independe do lugar e pode acontecer até em locais mais precários. Contudo, não devemos nos contentar com o estado de sucateamento em que se encontram as escolas públicas. Por outro lado, também não podemos fazer disso um fator determinante para que não façamos um trabalho de qualidade. A falta de estrutura não pode se tornar motivo para privarmos nossos alunos do conhecimento. Conforme foi constatado durante a pesquisa, o Ferroviário, apesar dos problemas enfrentados, com a uniáo do corpo docente a busca por qualidade foi bem-sucedida.

Sendo assim, pressupóe-se que, do mesmo modo que foi possível se obter êxito nesta instituição, também é possível que aconteça em outras, uma vez que depende em grande parte do desejo de mudança da comunidade escolar e do comprometimento desta com o que se propóe a fazer em prol de tal mudança.

Vale ressaltar a importância do incentivo à leitura, tendo em vista que é por meio dela que se conseguem melhores resultados no processo de ensino e aprendizagem e, mais que isso, como prática social, ela é fundamental para levar o indivíduo a adquirir capacidade crítica para atuar socialmente e modificar a realidade em que vive, transformando o sonho de um futuro melhor em realidade.

\section{Referências}

ANDRÉ, B. P.; AZEVEDO, S. M.; SILVA, R. B.; SILVA, C. A.; CURTY, L. E. S. O despertar do gosto pela leitura: uma biblioteca com saber e sabor. Revista Conexão, vol. 11, 2: 206-217, Ponta Grossa, maio/agosto 2015.

BAMBERGER, Richard. Como incentivar o hábito de leitura. Trad. Octávio Mendes Cajado. 3. ed. São Paulo: Ática, 1987.

BRASIL. Lei no 12.244, de 24 de maio de 2010. Dispóe sobre a universalização das bibliotecas nas instituiçôes de ensino do pais. Brasília: Congresso Nacional, 2010.

Secretaria de Educação Fundamental. Parâmetros curriculares nacionais: língua portuguesa. Brasília: 1997, 144p. 
COELHO, N. N. Literatura e leitura em tempos de internet. Via Atlântica, 14: 75-80, São Paulo, dez. 2008.

FOUCAMBERT, Jean. A leitura em questão. Porto Alegre: Artmed, 1994.

FREIRE, Paulo. A importância do ato de ler: em três artigos que se completam. São Paulo: Cortez, 1989.

HEATHINGTON, B. S. Afeto versus habilidades: escolha para professores. In: CRAMER, E. H.; CASTLE, M (Orgs.). Incentivando o Amor pela Leitura. Porto Alegre: Artmed, 2001. p. 221-231.

JOHNS, J. L.; VANLEIRSBURG, P. Incentivando o Hábito da Leitura: Consideraçóes e Estratégias. In: CRAMER, E. H.; CASTLE, M (Orgs.). Incentivando o Amor pela Leitura. Porto Alegre: Artmed, 2001. p. 105-119.

KRAMER, Sônia. Leitura e escrita como experiência-notas sobre o seu papel na formação. In: ZACCUR, E. (Org.). A magia da Linguagem. Rio de Janeiro: DP\&A, 2001.

LOBATO, J. B. M. A onda verde. São Paulo: Brasiliense, 1969.

MIKULECKY, L. A necessidade de literatos afetivos. In: CRAMER, E. H.; CASTLE, M. (Orgs.). Incentivando o Amor pela Leitura. Porto Alegre: Artmed, 2001. p. 273-278.

SOARES, M. Linguagem e Escola: Uma perspectiva social. São Paulo: Ática, 2002.

. O livro didático e a escolarização da leitura: depoimento. [07 de outubro, 2002]; Disponível em: <http://entrevistasbrasil.blogspot.com. br/2008/10/magda-soares-o-livro-didtico-e.html> Acesso em: 20/02/2015. - Alfabetização e letramento. São Paulo: Contexto, 2005.

SOUZA, C. H. M.; GOMES, M. L. M. Educação e Ciberespaço. 1. ed. Brasília: Usina das Letras, 2008.

VYGOTSKY, L. S. A formação social da mente. São Paulo, Martins fontes, 1998.

ZILBERMAN, Regina. A literatura infantil na escola. São Paulo: Global, 2003. ZILBERMAN, Regina. O papel da literatura na escola. Via Atlântica, 14: 1122, São Paulo, dez. 2008. 


\title{
THE DEVELOPMENT OF READING SKILLS IN THE FINAL STAGE OF ELEMENTARY SCHOOL: FOCUSING ON THE REAL AND THE IDEAL PRACTICES
}

\begin{abstract}
Considering reading skills as a fundamental activity for the student's social education, it was researched how reading activities have been developed in classroom and what are their influences on the teaching-learning process. This research was conducted in a public school in Campos dos Goytacazes. The aim of this paper is to analyze how teachers from 5th year of Elementary School work the reading skills with their students.
\end{abstract}

KEYWORDS: Reading; School; Teacher.

Recebido em: 11/02/2015 Aprovado em: 20/08/2015 